\title{
Spectral Energy Distribution of the International Commis- sion on Illumination Light Sources A, B, and C
}

\author{
Raymond Davis, Kasson S. Gibson, and Geraldine Walker Haupt
}

\begin{abstract}
Standard light sources $\mathrm{A}, \mathrm{B}$, and $\mathrm{C}$ were adopted by the International Commission on Illumination (CIE) in 1931 for the colorimetry of materials. Source $\dot{A}$ is an incandescent lamp operated at $2,854^{\circ} \mathrm{K}$. Sources B and C, representative of average noon sunlight and average daylight, respectively, are produced by passing radiant flux from source $\AA$ through specified Davis-Gibson filters described in Bureau Miscellaneous Publication M114 (1931).

The CIE published relative energy data only from 370 to $720 \mathrm{~m} \mu$. The present paper gives data for these sources in the ultraviolet and extends the data in the red to $780 \mathrm{~m} \mu$. The new data were reported through the U. S. Secretariat Committee to the CIE at its 1951 meeting.
\end{abstract}

\section{Introduction}

In 1931 the International Commission on Illumination (Commission Internationale de l'Eclairage, CIE) recommended that three light sources, A, B, and $\mathrm{C}$, be adopted for the general colorimetry of materials [1]. ${ }^{1}$ These were defined as: A, a gasfilled lamp at the color temperature of $2,848^{\circ} \mathrm{K}$ $\left(c_{2}=14,350\right.$ micron degrees $) .^{2} \mathrm{~B}$, the same lamp used with a filter consisting of a layer, 1-cm thickness, of each of two solutions * * * contained in a double cell with colorless optical-glass plates. The compositions of the two solutions are specified in the resolution. $\mathrm{C}$, the same lamp in combination with a second filter of the same type but with different composition, also specified in the recommendation.

Source $\mathrm{A}$ is intended to be typical of light from the gas-filled tungsten-filamentincandescent lamp; source $\mathrm{B}$ is an approximate representation of noon sunlight; and source $\mathrm{C}$ is an approximate representation of average daylight (see fig. 1). The relative spectralenergy distributions for sources $\mathrm{B}$ and $\mathrm{C}$ are given in the CIE recommendations over the wavelength range from 370 to $720 \mathrm{~m} \mu$.

The two filters that, in combination with source A, comprise sources B and C are of the type designed by Davis and Gibson and described in detail in Bureau Miscellaneous Publication M114 [2]. They are two of a large number of such filters designed for the reproduction of the various phases of sunlight and daylight and the conversion of low to higher color temperatures. The particular filters used to obtain sources $\mathrm{B}$ and $\mathrm{C}$ are designated in [2] as $2,848^{\circ}$ to $4,800^{\circ} \mathrm{K}$ and $2,848^{\circ}$ to $6,500^{\circ} \mathrm{K}$ because they were designed to produce exactly the colors corresponding to $4,800^{\circ}$ and $6,500^{\circ} \mathrm{K}$, respectively, for the observer defined by the "Optical Society of America (OSA) excitations extrapolated". For the 1931 CIE standard observer $[3,4]$ and the modification of it tentatively proposed in 1951 [5], the colors produced are slightly too purple to match the colors of the black body at any temperature. The temperatures of the black body most similar to these colors (called correlated color temperatures) are as follows [6]:

${ }^{1}$ Figures in brackets indicate the literature references at the end of this paper. ${ }^{2}$ Equivalent to $2,854^{\circ} \mathrm{K}$, with $c_{2}=14,380$ micron aegrees.

\begin{tabular}{|c|c|c|c|c|c|c|}
\hline \multirow{3}{*}{ Observer } & \multicolumn{4}{|c|}{$\begin{array}{l}\text { Correlated color } \\
\text { temperature }\end{array}$} & \multirow{2}{*}{\multicolumn{2}{|c|}{$\begin{array}{l}\text { Departure from } \\
\text { design color } \\
\text { temperature }\end{array}$}} \\
\hline & \multicolumn{2}{|c|}{$c_{2}=14,350$} & \multicolumn{2}{|c|}{$c_{2}=14,380$} & & \\
\hline & $\underset{\mathrm{B}}{\text { Source }}$ & $\underset{\mathrm{C}}{\text { Source }}$ & $\underset{\mathrm{B}}{\text { Source }}$ & $\underset{\mathrm{C}}{\text { Source }}$ & $\underset{\mathrm{B}}{\text { Source }}$ & $\underset{\mathrm{C}}{\text { Source }}$ \\
\hline $\begin{array}{l}\text { OSA "Escita- } \\
\text { tions." }\end{array}$ & ${ }^{\circ} K$ & $\begin{array}{c}\circ K \\
6,500\end{array}$ & $\stackrel{\circ K}{4,810}$ & $\begin{array}{c}\circ K \\
6,514\end{array}$ & $\begin{array}{l}\mu r d \\
0.0\end{array}$ & $\begin{array}{l}\mu r d \\
0.0\end{array}$ \\
\hline $\begin{array}{l}\text { 1951 CIE tenta- } \\
\text { tive. }\end{array}$ & 4,815 & 6,560 & 4825 & 6,574 & .7 & 1. 4 \\
\hline $\begin{array}{l}1931 \text { CIE stand- } \\
\text { ard. }\end{array}$ & 4,860 & 6,726 & 4,870 & 6,740 & 2.6 & 5. 4 \\
\hline
\end{tabular}

From the indicated departures from the design color temperatures of $4,800^{\circ}$ and $6,500^{\circ} \mathrm{K}$, respectively, it will be noted that these designations are only approximate if the 1931 CIE standard observer is used to assess the colors. But if the tentative 1951 modified observer is used, the designations may be considered precise for ordinary observing conditions under which differences in reciprocal color

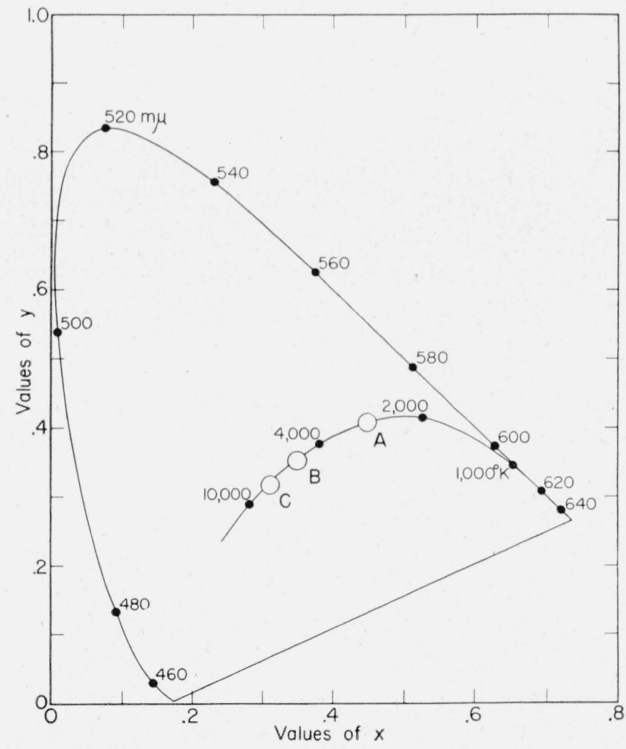

Figure 1. Chromaticities of CIE light sources $A, B$, and $C$, together with spectrum locus and black-body locus, plotted on the 1931 CIE chromaticity diagram.

Those unfamiliar with this ehromaticity diagram will find it discussed in references $[1,3,4$, and 6$]$. 
temperature in the neighborhood of $1.0 \mu \mathrm{rd}$ (microreciprocal-degree) are imperceptible.

Regardless of this, however, the spectral distributions of CIE light sources B and C define these sources in unambiguous terms, irrespective of observer or color temperature, and these distributions give approximately the colors of noon sunlight and average daylight.

It happened that charts illustrating these particular filters and the resulting spectral distributions were not given [2] among those chosen for illustration. The chart for the $2,848^{\circ}$ to $4,800^{\circ} \mathrm{K}$ filter and source was later published [7] but that for the $2,848^{\circ}$ to $6,500^{\circ} \mathrm{K}$ filter has not been published. Accordingly, as a matter of convenience, these are both reproduced in slightly revised form in the present paper, see figures 2 and 3 . Hereafter the sources (and filters) will be designated as sources $\mathrm{B}$ and $\mathrm{C}$ (or filters $\mathrm{B}$ and $\mathrm{C}$ ), as they were designated by the CIE in 1931.
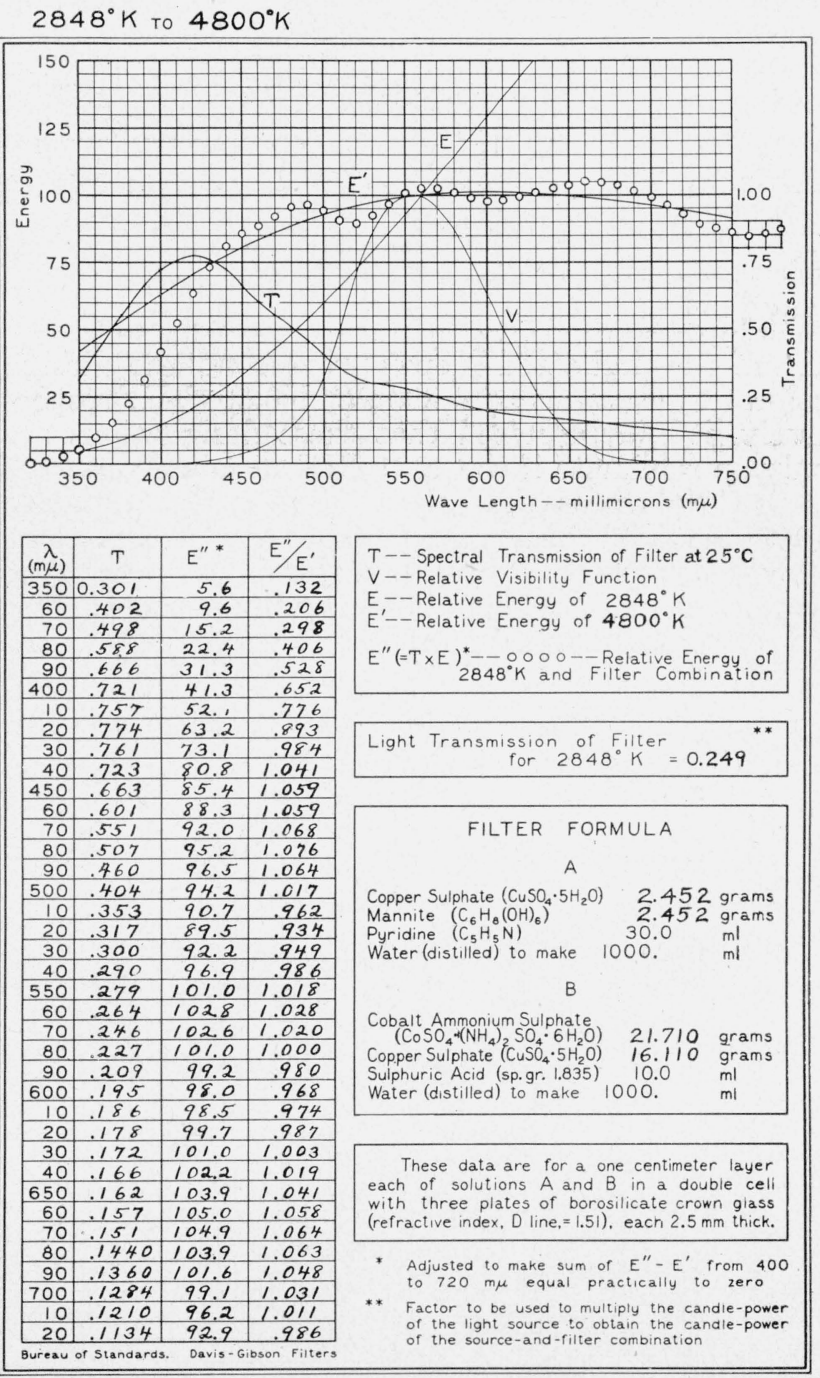

Figure 2. CIE light source $B$.

Spectrophotometric data, and other information on this source and the filter used to obtain it. This chart is similar to the charts of reference [2] and [7]. Values below 350 and above $720 \mathrm{~m} \mu$ are given in table 4 .
Figures 1, 2, and 3 give considerable information about these filters and the resulting light sources. Many other details relating to the filters are given in the original publication [2].

In the (U. S.) Secretariat questionnaire and report prepared for the 1948 meetings of the CIE in Paris [8], the question of standard sources was raised anew, and the following question was asked:

"In view of the possible influence of ultraviolet irradiation on the colours of fluorescent samples, do you believe that the definition of standard illuminant $\mathrm{A}, \mathrm{B}$ and $\mathrm{C}$ should be made more precise in regard to the ultraviolet?"

The authors of [2] offered to extend the data for sources B and C below $350 \mathrm{~m} \mu$ if that seemed desirable.

Replies to the above question were received from several countries, and after discussion at the meetings the following recommendation was adopted [8]:

$2848^{\circ} \mathrm{K}$ TO $6500^{\circ} \mathrm{K}$ CHART 27
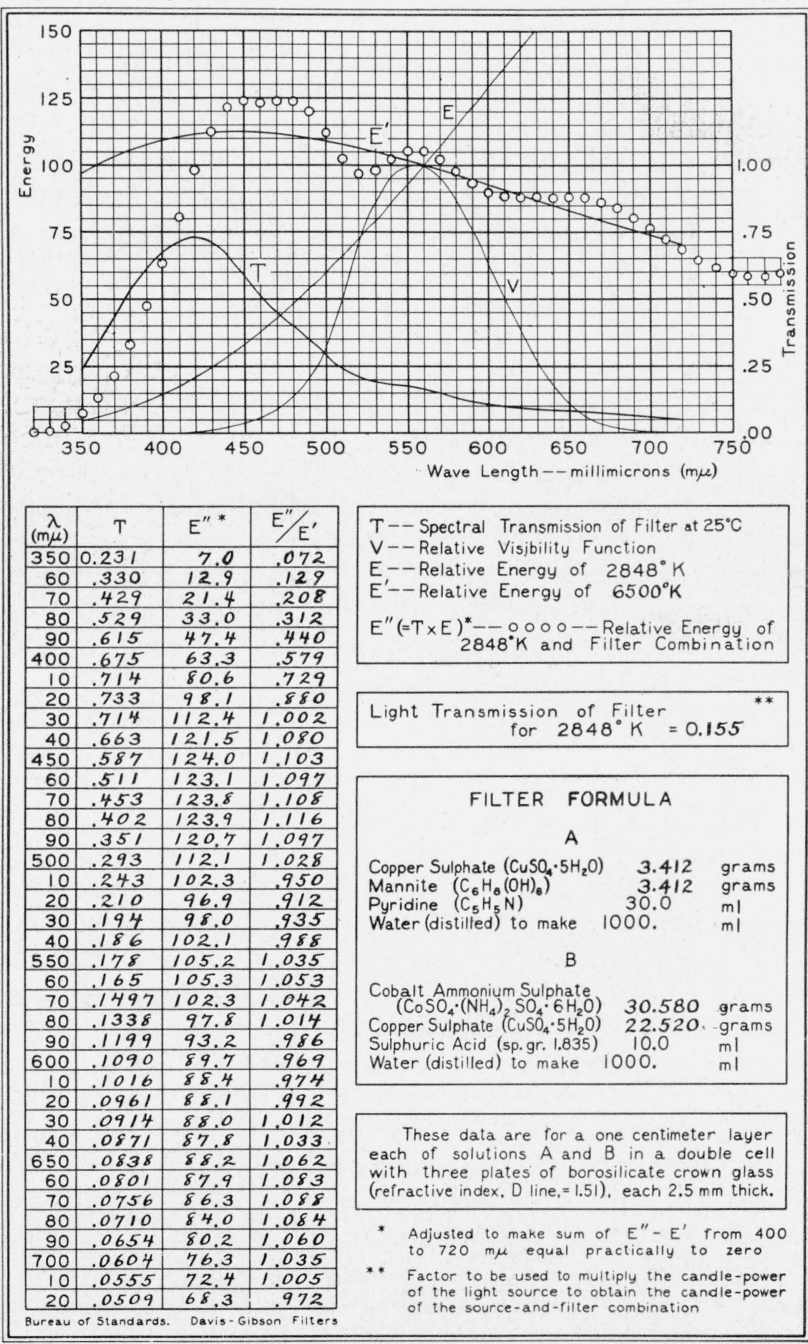

Figure 3. CIE light source $C$. Spectrophotometric data and other information on this source and the filter
used to obtain it. This chart is similar to those of reference [2]. Values below 350 and above $720 \mathrm{~m} \mu$ are given in table 4 . 
"Ultraviolet Content of Standard Illuminants.-(a) It is recommended that the offer made through the United States Committee by Messrs. Davis and Gibson to determine the relative energy distributions of illuminants $\mathrm{B}$ and $\mathrm{C}$ below $370 \mathrm{~m} \mu$, including the spectral transmission factor of the cells, be accepted."

It was also recommended that the National Committees study the question of a standard source having relatively more ultraviolet energy than sources $\mathrm{A}, \mathrm{B}$, and $\mathrm{C}$ for the colorimetry of fluorescent materials.

In compliance with the first recommendation, the spectral transmittances of the $\mathrm{B}$ and $\mathrm{C}$ filters have been redetermined and extended in the ultraviolet, and these transmittances and the resulting spectral energy distributions were reported to the 1951 meetings of the Commission in Stockholm through the (U. S.) Secretariat Committee [9].

The present paper describes the measurements on which these new data are based, and gives the resulting values over the spectral range from 320 to $400 \mathrm{~m} \mu$. In addition, there are given some published and unpublished data for the long-wave end of the visible spectrum. In the charts of reference [2], as illustrated in figures 2 and 3 of the present paper, the data covered the visible range only to $720 \mathrm{~m} \mu$, this being the long-wave limit of the OSA excitations used in that work. However, the spectrophotometric data on the component filter parts had been determined to $750 \mathrm{~m} \mu$ [2], so that extension of the transmission and energy data could readily be made.

When the CIE distributions defining the new standard observer were adopted, they were extended as far as $780 \mathrm{~m} \mu$ [1]. At the request of Smith and Guild [3] values of relative energy for sources B and $\mathrm{C}$ were extended to $780 \mathrm{~m} \mu$. These values were published in table V, p. 102 , of their paper. They were also published by Judd [4]. As the data entering into this extension of values have never been published, they are given in the present paper.

\section{Spectrophotometric Measurements and Computations}

The spectral transmittances of the filters (designated as spectral transmissions in [2]), given in figures 2 and 3 in the columns headed $T$ were derived by computation from spectrophotometric measurements made on certain standard solutions, as explained in [2], including a study of Beer's law for the respective components over the range of concentrations of interest. This previous spectrophotometric work on the standard solutions was very extensive. It involved, for each standard component of the filter, measurements with several different solutions, at cell thicknesses from 1 to $10 \mathrm{~cm}$ and with three or four spectrophotometers. A detailed discussion of these measurements is given in [2]. All data were obtained at $25^{\circ} \mathrm{C}$. Check measurements were also made on the complete filters.

No such elaborate series of measurements was considered necessary for the present purpose, which was primarily to extend the values of spectral transmittance and energy below $350 \mathrm{~m} \mu$, as far as there was significant transmittance. Because the filter cell contains three borosilicate glass plates of total thickness of about $7 \mathrm{~mm}$, this transmittance could not in any case extend much below $300 \mathrm{~m} \mu$.

Two sets of solutions were prepared, one in February 1950 and one in January 1951. Spectrophotometric measurements were made on each set of solutions within 1 to 4 weeks from the date of preparation. In each case two methods of determining the filter transmittance were used: (1) The spectral transmittancies of the four standard filter components were measured and the transmittances of the B and C filters computed for the appropriate concentrations, as was done for all the filters of [2], (2) direct measurements of spectral transmittance were made on B and C filters prepared in accordance with the specifications.

The Beckman quartz (DU) spectrophotometer was used for all the present measurements, with temperatures of filters and components kept at $25^{\circ} \mathrm{C}$. The 1950 and 1951 measurements were equivalent in every respect, the repetition being made to obtain greater certainty in the results. The 1950-51 data presented are averages of the results obtained.

\subsection{Standard Filter Components}

These components are the $\mathrm{A}^{\prime}, \mathrm{B}_{1}^{\prime}$, and $\mathrm{B}_{2}^{\prime}$ solutions, and the double cell filled with distilled water. They are as follows [2]:

\section{Solution $A^{\prime}$}

Unfiltered, thickness $10.00 \mathrm{~mm}$, temperature $25^{\circ}$ $\mathrm{C}$, having the composition:

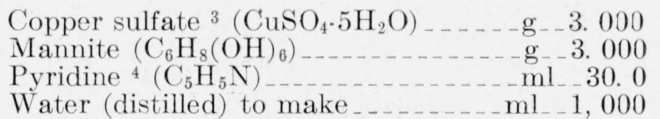

\section{Solution B}

Unfiltered, thickness $10.00 \mathrm{~mm}$, temperature $25^{\circ}$ $\mathrm{C}$, having the composition:

Copper sulfate $\left(\mathrm{CuSO}_{4} \cdot 5 \mathrm{H}_{2} \mathrm{O}\right)$
Sulfuric acid (specific gravity 1.835$)_{-} \mathrm{ml}_{-} 10.00$
Water (distilled) to make 1000

\section{SOLUTION $\mathrm{B}_{2}^{\prime}$}

Unfiltered, thickness $10.00 \mathrm{~mm}$, temperature $25^{\circ}$ $\mathrm{C}$, having the composition: ${ }^{5}$

$$
\begin{aligned}
& \text { Cobalt ammonium sulfate }{ }^{6} \\
& \quad\left(\mathrm{CoSO}_{4} \cdot\left(\mathrm{NH}_{4}\right)_{2} \mathrm{SO}_{4} \cdot 6 \mathrm{H}_{2} \mathrm{O}\right) \\
& \text { Sulfuric acid (specific gravity } 1.835)_{-} \mathrm{ml}_{-} 10.0 \\
& \text { Water (distilled) to make } 14.481 \\
&
\end{aligned}
$$

${ }^{3}$ Chemical analysis showed the copper sulfate to have 99.7 percent of the theoretical copper content.

4 Titration showed the pyridine to have an effective strength of 98.4 percent, including $21 / 2$ percent of picoline as an impurity.

5 These data apply also throughout the visible spectrum to a similar solution made up with $10.3 \mathrm{~g}$ of cobalt sulfate $\left(\mathrm{C}_{0} \mathrm{SO}_{4} \cdot 7 \mathrm{H}_{2} \mathrm{O}\right)$.

made up with analysis showed a cobalt (plus nickel) content of 100.0 percent of the theoretical, the ratio of nickel to cobalt (metals) being 1 to 200. 


\section{Glass-Water Double Cell}

Three glass plates, each approximately $2.4 \mathrm{~mm}$ thick (borosilicate crown, refractive index, $D$ line,$=$ approximately 1.52$)$; two $1.000-\mathrm{cm}$ thicknesses of distilled water; two air-glass surfaces; four glasswater surfaces.

The spectral transmittancies of the $\mathrm{A}^{\prime}, \mathrm{B}_{1}^{\prime}$, and $\mathrm{B}_{2}^{\prime}$ solutions (relative to distilled water) were measured in $1.000-\mathrm{cm}$ cells with quartz end plates over the range from 300 to $400 \mathrm{~m} \mu$ and at 404.7 and 435.8 $\mathrm{m} \mu .^{7} \quad$ The transmittance of the glass-water double cell was measured at the same wavelengths. ${ }^{8}$

\begin{tabular}{|c|c|c|c|}
\hline \multirow{2}{*}{ Solution } & \multirow{2}{*}{$\begin{array}{l}\text { Wave- } \\
\text { length }\end{array}$} & \multicolumn{2}{|c|}{ Transmittancy } \\
\hline & & Observed & $\begin{array}{c}\text { Reference } \\
{[2]}\end{array}$ \\
\hline $\begin{array}{l}\mathrm{A}^{\prime}, \ldots \\
\mathrm{B}_{1}^{\prime} \\
\mathrm{B}_{2}^{\prime}\end{array}$ & $\begin{array}{c}m \mu \\
587.6 \\
667.8 \\
501.6\end{array}$ & $\begin{array}{r}0.208 \\
.483 \\
.679\end{array}$ & $\begin{array}{r}0.207 \\
.480 \\
.682\end{array}$ \\
\hline
\end{tabular}

The purpose of the determinations at 435.8 and $404.7 \mathrm{~m} \mu$ was to give correlation with the standard values in [2]. As is shown in that publication, the most extensive and reliable spectrophotometric determinations were made at eight $\mathrm{Hg}$ and $\mathrm{He}$ wavelengths, including these two. Below $404.7 \mathrm{~m} \mu$ the standard values were subject to increasing uncertainty.

7 In addition, a measurement at a region of relatively high absorption in the visible was made with each solution as a check on the concentration. The following values were obtained and were considered to be satisfactory checks, the deviation in each being less than 1 percent of the value:

8 As a matter of interest, the spectral transmittancies of the three standard As a matter of interest, the spectral transmittancies of the three standard
solutions were also examined in $1-\mathrm{cm}$ thicknesses between 210 and $300 \mathrm{~m} \mu$. No

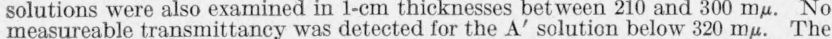
measureable transmittancy was detected for the $A^{\prime}$ solution below $320 \mathrm{~m} \mu$. The
transmittancy of the $\mathrm{B}^{\prime}$ s solution decreases rapidly below $300 \mathrm{~m} \mu$, approaching zero at $270 \mathrm{~m} \mu$ and having no measureable value below this wavelength. The $\mathrm{B}$ ? solution transmits freely between 210 and $300 \mathrm{~m} \mu$.
It was believed that the best correlation between the present measurements and the previous determinations would be obtained if the present values of transmittancy and transmittance were adjusted slightly, if necessary, to bring them into agreement with the previous standard values at these two wavelengths, 435.8 and $404.7 \mathrm{~m} \mu$; the resulting degree of agreement from 400 to $350 \mathrm{~m} \mu$ could then be studied and new standard values for the four components from 300 to $400 \mathrm{~m} \mu$ thereupon adopted. These adjustment factors, the averages of $T_{[2]} / T_{1950-51}$ for the two $\mathrm{Hg}$ wavelengths, were as follows:

\begin{tabular}{|c|c|c|c|}
\hline \multirow{2}{*}{ Component } & \multicolumn{2}{|c|}{ Ratio: $T_{[2]} / T_{1950-51}$} & \multirow{2}{*}{$\begin{array}{l}\text { Adjustment } \\
\text { factor }\end{array}$} \\
\hline & $404.7 \mathrm{~m} \mu$ & $435.8 \mathrm{~m} \mu$ & \\
\hline $\begin{array}{l}\mathrm{A}^{\prime} \\
\mathrm{B}_{1}^{\prime} \\
\mathrm{B}_{2}^{\prime} \\
\mathrm{W}^{\prime}\end{array}$ & $\begin{array}{l}1.0130 \\
1.0030 \\
1.0073 \\
0.9966\end{array}$ & $\begin{array}{l}1.0095 \\
1.0040 \\
1.0067 \\
1.0011\end{array}$ & $\begin{array}{l}1.011 \\
1.004 \\
1.007 \\
0.999\end{array}$ \\
\hline
\end{tabular}

In table 1 are given these adjusted values of transmittancy or transmittance for the various components, together with the values previously published in [2] and the newly adopted values. The following comments may be made regarding these values:

1. In deriving the adopted values, weights of 10,8 , $6,4,2$, and 0 were given to the former values at 400 , $390,380,370,360$, and $350 \mathrm{~m} \mu$, respectively. Corresponding weights of $0,2,4,6,8$, and 10 were given to the 1950-51 adjusted values at these same wavelengths. From 340 to $300 \mathrm{~m} \mu$ the $1950-51$ adjusted values were used.

2. Solutions $B_{1}^{\prime}$ and $B_{2}^{\prime}$ show very close agreement between the former values and the 1950-51 adjusted values. Although there are no certain differences

TABLE 1. Revision and extension of standard data for Davis-Gibson filter components Solutions $\mathrm{A}^{\prime}, \mathrm{B}_{1}$, and $\mathrm{B}_{2}^{\prime}$, and double glass cell filled with distilled water, $\mathrm{W}$

\begin{tabular}{|c|c|c|c|c|c|c|c|c|c|c|c|c|}
\hline \multirow{3}{*}{ Wavelength } & \multicolumn{9}{|c|}{ Transmittancy, $10.00 \mathrm{~mm}$, at $25^{\circ} \mathrm{C}$} & \multicolumn{3}{|c|}{$\begin{array}{l}\text { Transmittance at } 25^{\circ} \mathrm{C} \\
\text { of glass-water cell, W. }\end{array}$} \\
\hline & \multicolumn{3}{|c|}{ Solution $\mathrm{A}^{\prime}$} & \multicolumn{3}{|c|}{ Solution $\mathrm{B}_{1}^{\prime}$} & \multicolumn{3}{|c|}{ Solution $\mathrm{B}_{2}^{\prime}$} & \multirow[b]{2}{*}{$\begin{array}{c}\text { Refer. } \\
\text { ence } \\
{[2]}\end{array}$} & \multirow{2}{*}{$\begin{array}{l}1950-51 \\
\text { average, } \\
\text { adjusted } \\
(f=0.999)\end{array}$} & \multirow[b]{2}{*}{$\begin{array}{l}\text { Adopted } \\
\text { values }\end{array}$} \\
\hline & $\begin{array}{c}\text { Refer- } \\
\text { ence } \\
{[2]}\end{array}$ & $\begin{array}{c}1950-51 \\
\text { average, } \\
\text { adjusted } \\
(f=1.011)\end{array}$ & $\begin{array}{c}\text { Adopted } \\
\text { values }\end{array}$ & $\begin{array}{l}\text { Refer- } \\
\text { ence } \\
{[2]}\end{array}$ & $\begin{array}{c}1950-51 \\
\text { average, } \\
\text { adjusted } \\
(f=1.004)\end{array}$ & $\begin{array}{c}\text { Adopted } \\
\text { values }\end{array}$ & $\begin{array}{c}\text { Refer- } \\
\text { ence } \\
{[2]}\end{array}$ & $\begin{array}{c}1950-51 \\
\text { average, } \\
\text { adjusted } \\
(f=1.007)\end{array}$ & $\begin{array}{c}\text { Adopted } \\
\text { values }\end{array}$ & & & \\
\hline \begin{tabular}{c}
\multicolumn{2}{c}{$m \mu$} \\
300 \\
310 \\
320 \\
330 \\
340
\end{tabular} & 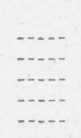 & $\begin{array}{l}0.000 \\
.000 \\
.006 \\
.069 \\
.214\end{array}$ & $\begin{array}{r}0.000 \\
.000 \\
.006 \\
.069 \\
.214\end{array}$ & 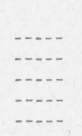 & $\begin{array}{r}0.548 \\
.788 \\
.899 \\
.945 \\
.968\end{array}$ & $\begin{array}{l}0.548 \\
.788 \\
.899 \\
.945 \\
.968\end{array}$ & 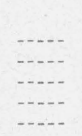 & $\begin{array}{r}0.986 \\
.988 \\
.989 \\
.991 \\
.992\end{array}$ & $\begin{array}{r}0.986 \\
.988 \\
.989 \\
.991 \\
.992\end{array}$ & 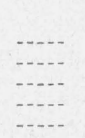 & $\begin{array}{r}0.010 \\
.102 \\
.314 \\
.536 \\
.702\end{array}$ & $\begin{array}{r}0.010 \\
.102 \\
.314 \\
.536 \\
.702\end{array}$ \\
\hline $\begin{array}{l}350 \\
360 \\
370 \\
380 \\
390\end{array}$ & $\begin{array}{l}0.339 \\
.437 \\
.541 \\
.646 \\
.746\end{array}$ & $\begin{array}{l}.334 \\
.426 \\
.528 \\
.636 \\
.737\end{array}$ & $\begin{array}{l}.334 \\
.428 \\
.533 \\
.642 \\
.744\end{array}$ & $\begin{array}{r}0.979 \\
.986 \\
.989 \\
.992 \\
.994\end{array}$ & $\begin{array}{l}.980 \\
.986 \\
.991 \\
.994 \\
.994\end{array}$ & $\begin{array}{l}.980 \\
.986 \\
.990 \\
.993 \\
.994\end{array}$ & $\begin{array}{r}0.991 \\
.991 \\
.989 \\
.985 \\
.980\end{array}$ & $\begin{array}{l}.992 \\
.992 \\
.990 \\
.986 \\
.978\end{array}$ & $\begin{array}{r}.992 \\
.992 \\
.990 \\
.985 \\
.980\end{array}$ & $\begin{array}{l}0.817 \\
.851 \\
.873 \\
.885 \\
.889\end{array}$ & $\begin{array}{l}.798 \\
.848 \\
.870 \\
.869 \\
.886\end{array}$ & $\begin{array}{l}.798 \\
.849 \\
.871 \\
.879 \\
.888\end{array}$ \\
\hline $\begin{array}{l}400 \\
404.7 \\
435.8\end{array}$ & $\begin{array}{l}.825 \\
.855 \\
.959\end{array}$ & $\begin{array}{l}.821 \\
.854 \\
.960\end{array}$ & $\begin{array}{l}.825 \\
.855 \\
.959\end{array}$ & $\begin{array}{l}.995 \\
.995 \\
.997\end{array}$ & $\begin{array}{l}.995 \\
.996 \\
.996\end{array}$ & $\begin{array}{l}.995 \\
.995 \\
.997\end{array}$ & $\begin{array}{l}.972 \\
.967 \\
.904\end{array}$ & $\begin{array}{l}.969 \\
.967 \\
.904\end{array}$ & $\begin{array}{l}.972 \\
.967 \\
.904\end{array}$ & $\begin{array}{l}.891 \\
.892 \\
.895\end{array}$ & $\begin{array}{l}.893 \\
.894 \\
.893\end{array}$ & $\begin{array}{l}.891 \\
.892 \\
.895\end{array}$ \\
\hline $\begin{array}{l}750 \\
760 \\
770 \\
780\end{array}$ & $\begin{array}{l}.446 \\
\text { \&. } 471 \\
\text { \&. } 497 \\
\text { \&. } 522\end{array}$ & - & $\begin{array}{l}.446 \\
.471 \\
.497 \\
.522\end{array}$ & $\begin{array}{l}.152 \\
\text { \&. } 139 \\
\text { a. } 129 \\
\text { ஃ. } 122\end{array}$ & - & $\begin{array}{l}.152 \\
.139 \\
.129 \\
.122\end{array}$ & $\begin{array}{r}.994 \\
\approx .994 \\
\text { ×. } 994 \\
\approx .994\end{array}$ & - & $\begin{array}{r}.994 \\
.994 \\
.994 \\
.994\end{array}$ & $\begin{array}{l}.861 \\
\text { b. } 862 \\
\text { b. } 864 \\
\text { b. } 866\end{array}$ & - & $\begin{array}{l}.861 \\
.862 \\
.864 \\
.866\end{array}$ \\
\hline
\end{tabular}

- Extrapolated, unpublished.

b Unpublished experimental data obtained at same time as data of [2]. 
between the two sets of data, the same system of weighting was used in adopting the final values.

3. Below $400 \mathrm{~m} \mu$ there were slight but consistent differences between the 1950 and 1951 data for the $\mathrm{A}^{\prime}$ solutions. However, neither set of data differed from the average (either before or after adjustment) by more than 0.01 at any wavelength. Further work was considered unwarranted.

4. With the double glass cell filled with water a slight absorption band centering at $380 \mathrm{~m} \mu$ was noted in the present determinations. This is caused by the glass plates and was not detected in the previous measurements. This is considered further in the next section.

5. The values at $750 \mathrm{~m} \mu$ are as published in [2]. The values from 760 to $780 \mathrm{~m} \mu$ for the three solutions were obtained by extrapolating the final $-\log _{10} \mathrm{~T}$ versus $\lambda$ curves, on which the data of [2] are based. The uncertainty of this extrapolation increases of course as the wavelength interval from $750 \mathrm{~m} \mu$ increases. At 760 and $770 \mathrm{~m} \mu$ this uncertainty is considered very small, and the reliability of the values at these two wavelengths is considered wholly adequate for the purpose. For the glass-water cell, the values are as measured in 1926 and show clearly the water absorption band near $750 \mathrm{~m} \mu$.

\subsection{Glass-Water Double Cell}

A precise duplication of the spectral energy distributions given herein for sources $\mathrm{B}$ and $\mathrm{C}$ depends, among other things, on the adequate duplication of the spectral transmittance of the two-compartment glass cell when filled with distilled water. Borosilicate crown glass varies slightly in its index of refraction and in its spectral transmittance, particularly in the ultraviolet.

The $D$-line index of the glass used in 1926 to obtain the published data [2] was about 1.51. A new supply of borosilicate crown glass was obtained in 1929 with an index of about 1.52. This was used in the present measurements, the original pieces no longer being available. The agreement in spectral transmittance from 350 to $435.8 \mathrm{~m} \mu$, table 1 , indicates that no important difference in the visible spectrum is to be expected. This has also been confirmed many times during the years by spectrophotometric measurements throughout the visible on various of the Davis-Gibson filters.

The slight absorption band centering at $380 \mathrm{~m} \mu$ (table 1) was not detected in the 1926 measurements, those data having been derived from measurements made only at the mercury wavelengths below $400 \mathrm{~m} \mu$. With the Beckman spectrophotometer this band can be readily measured. It is present in all of the few samples of borosilicate crown recently measured, but in varying degree. It is probably caused by iron impurities since a greenish slide rule glass showed the band very strikingly.

This slight absorption has been ignored because (1) it varies from one glass to another, so that an extensive study would be necessary to determine what would be the most probable or representative value. It is, of course, also possible that some boro- silicate crown glass would not show this slight absorption band, (2) needless confusion would be caused by the resulting trivial and unimportant changes in the energy distributions of the $\mathrm{B}$ and $\mathrm{C}$ sources.

Below $360 \mathrm{~m} \mu$ there is some scatter among the spectral transmittances of different borosilicate crown glasses. This is also of little importance, however, because of the much greater absorption of the copperpyridine $\left(\mathrm{A}^{\prime}\right)$ solution, as shown in table 1 .

In accordance with the CIE request there are given in table 2 the complete spectral transmittance data for the double glass cell filled with water entering into the derivation of the energy distributions of the $\mathrm{B}$ and $\mathrm{C}$ sources over the range from 300 to $780 \mathrm{~m} \mu .^{9}$

TABLE 2. Spectral transmittance of glass-water double cell Three glass plates, each $2.4^{\mathrm{s}} \mathrm{mm}$ thick (borosilicate crown, refractive index, $D$ line $=1.52$ a, two 1.000-cm thicknesses of distilled water; two air-glass surfaces, four glass-water surfaces.

\begin{tabular}{|c|c|c|c|}
\hline $\begin{array}{l}\text { Wave- } \\
\text { length }\end{array}$ & $\begin{array}{l}\text { Trans- } \\
\text { mittance }\end{array}$ & $\begin{array}{l}\text { Wave- } \\
\text { length }\end{array}$ & $\begin{array}{l}\text { Trans- } \\
\text { mittance }\end{array}$ \\
\hline $\begin{array}{r}m \mu \\
290 \\
300 \\
10 \\
20 \\
30 \\
40 \\
350 \\
60 \\
70 \\
80 \\
90 \\
400 \\
10 \\
20 \\
30 \\
40 \\
450 \\
60 \\
70 \\
80 \\
90 \\
500 \\
10 \\
20 \\
30 \\
40\end{array}$ & $\begin{array}{l}0.000 \\
.010 \\
.102 \\
.314 \\
.536 \\
.702 \\
.798 \\
.849 \\
.871 \\
.885 \\
.889 \\
.891 \\
.892 \\
.893 \\
.894 \\
.895 \\
.896 \\
.897 \\
.898 \\
.960 \\
.901 \\
.902 \\
.903 \\
.904 \\
.904 \\
.904\end{array}$ & $\begin{array}{r}m \mu \\
550 \\
60 \\
70 \\
80 \\
90 \\
600 \\
10 \\
20 \\
30 \\
40 \\
650 \\
60 \\
70 \\
80 \\
90 \\
700 \\
10 \\
20 \\
30 \\
40 \\
750 \\
60 \\
70 \\
80\end{array}$ & $\begin{array}{l}0.904 \\
.904 \\
.904 \\
.904 \\
.903 \\
.902 \\
.902 \\
.902 \\
.901 \\
.900 \\
.900 \\
.900 \\
.900 \\
.900 \\
.898 \\
.897 \\
.893 \\
.883 \\
.871 \\
.863 \\
.861 \\
.862 \\
.864 \\
.866\end{array}$ \\
\hline
\end{tabular}

a From 380 to $780 \mathrm{~m} \mu$ the values were obtained with $2.5-\mathrm{mm}$ plates with index 1.51 [2], but within the uncertainties of the data and the variability of borosilicate crown glass the data are valid for the conditions specified.

By measuring the spectral transmittance of his own glass-water cell, any user of these filters can tell if there are any important deviations of his cell from those of the authors.

\subsection{B and C Filters}

a. Computed Values

Based on the newly adopted standard components data of table 1 , and by the same methods as previously used in the computation of such filters [2], the spectral transmittances of the B and C filters were computed and are shown in table 3 .

\section{b. Observed Values}

In both 1950 and 1951, as already noted, spectrophotometric measurements were made directly on B

DAt 380 and $390 \mathrm{~m} \mu$ these values'agree with the "Reference [2] values" rather than with the "adopted values" of table 1 . The adopted values of table 1 were used in deriving the computed values of table 3 , as indicated. However, since the energy distributions of the $\mathrm{B}$ and $\mathrm{C}$ sources and the spectral transmittances of the $\mathrm{B}$ and $\mathrm{C}$ filters were kept unchanged at 380 and $390 \mathrm{~m} \mu$ for reasons given in section 2.3 . c, the appropriate values for table 2 should be as given therein. 
TABLE 3. Revision and extension of standard data for filters and light sources $B$ and $C$

\begin{tabular}{|c|c|c|c|c|c|c|c|c|c|c|c|c|}
\hline \multirow{3}{*}{$\begin{array}{l}\text { Wave- } \\
\text { length }\end{array}$} & \multicolumn{4}{|c|}{ Spectral transmittance of filter B } & \multicolumn{2}{|c|}{$\begin{array}{l}\text { Relative energy } \\
\text { distribution of } \\
\text { source B }\end{array}$} & \multicolumn{4}{|c|}{ Spectral transmittance of filter $\mathrm{C}$} & \multicolumn{2}{|c|}{$\begin{array}{l}\text { Relative energy } \\
\text { distribution of } \\
\text { source C }\end{array}$} \\
\hline & & $1950-5$ & 1 data & & & & & $1950-5$ & 1 data & & & \\
\hline & $\begin{array}{l}\text { Former } \\
\text { values }\end{array}$ & $\begin{array}{l}\text { Comput- } \\
\text { ed from } \\
\text { adopted } \\
\text { values of } \\
\text { table } 1\end{array}$ & $\begin{array}{c}\text { Observed } \\
\text { values } \\
\text { (no ad- } \\
\text { justment) }\end{array}$ & $\begin{array}{l}\text { New } \\
\text { values }\end{array}$ & $\begin{array}{l}\text { Former } \\
\text { values }\end{array}$ & $\begin{array}{l}\text { New } \\
\text { values }\end{array}$ & $\begin{array}{l}\text { Former } \\
\text { values }\end{array}$ & $\begin{array}{l}\text { Comput- } \\
\text { ed from } \\
\text { adopted } \\
\text { values of } \\
\text { table } 1\end{array}$ & $\begin{array}{c}\text { Observed } \\
\text { values } \\
\text { (no ad- } \\
\text { justment) }\end{array}$ & $\begin{array}{c}\text { New } \\
\text { values }\end{array}$ & $\begin{array}{l}\text { Former } \\
\text { values }\end{array}$ & $\begin{array}{c}\text { New } \\
\text { values }\end{array}$ \\
\hline $\begin{array}{l}\mathrm{m} \mu \\
300 \\
310 \\
320 \\
330 \\
340\end{array}$ & 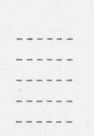 & $\begin{array}{r}0.000 \\
.000 \\
.003 \\
.049 \\
.176\end{array}$ & $\begin{array}{r}0.000 \\
.001 \\
.004 \\
.047 \\
.173\end{array}$ & $\begin{array}{r}0.000 \\
.000 \\
.003 \\
.048 \\
.175\end{array}$ & (n. & $\begin{array}{l}0.02 \\
.5 \\
2.4\end{array}$ & H. & $\begin{array}{r}0.000 \\
.000 \\
.001 \\
.027 \\
.126\end{array}$ & $\begin{array}{r}0.000 \\
.000 \\
.001 \\
.022 \\
.114\end{array}$ & $\begin{array}{r}0.000 \\
.000 \\
.001 \\
.025 \\
.120\end{array}$ & - & $\begin{array}{l}0.0_{1} \\
2.4\end{array}$ \\
\hline $\begin{array}{l}350 \\
360 \\
370 \\
380 \\
390 \\
400\end{array}$ & $\begin{array}{r}0.309 \\
.403 \\
.498 \\
.588 \\
.666 \\
.721\end{array}$ & $\begin{array}{l}.298 \\
.396 \\
.492 \\
.585 \\
.664 \\
.722\end{array}$ & $\begin{array}{l}.304 \\
.407 \\
.504 \\
.585 \\
.666 \\
.725\end{array}$ & $\begin{array}{l}.301 \\
.402 \\
.498 \\
.588 \\
.666 \\
.721\end{array}$ & $\begin{array}{r}5.7 \\
9.7 \\
15.2 \\
22.4 \\
31.3 \\
41.3\end{array}$ & $\begin{array}{r}5.6 \\
9.6 \\
15.2 \\
22.4 \\
31.3 \\
41.3\end{array}$ & $\begin{array}{r}0.243 \\
.335 \\
.433 \\
.529 \\
.615 \\
.675\end{array}$ & $\begin{array}{l}.234 \\
.328 \\
.427 \\
.525 \\
.613 \\
.676\end{array}$ & $\begin{array}{l}.228 \\
.331 \\
.431 \\
.520 \\
.612 \\
.680\end{array}$ & $\begin{array}{l}.231 \\
.330 \\
.429 \\
.529 \\
.615 \\
.675\end{array}$ & $\begin{array}{r}7.4 \\
13.2 \\
21.6 \\
33.0 \\
47.4 \\
63.3\end{array}$ & $\begin{array}{r}7.0 \\
12.9 \\
21.4 \\
33.0 \\
47.4 \\
63.3\end{array}$ \\
\hline $\begin{array}{l}720 \\
730 \\
740 \\
750 \\
760 \\
770 \\
780\end{array}$ & $\begin{array}{l}.1134 \\
\text { a. } 1063 \\
\text { a. } 1007 \\
\text { a. } 0964 \\
\text { a. } 0938 \\
\text { a. } 0926 \\
\text { a. } 0925\end{array}$ & 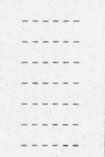 & & $\begin{array}{l}.1134 \\
.1063 \\
.1007 \\
.0964 \\
.0938 \\
.0926 \\
.0925\end{array}$ & $\begin{array}{c}92.9 \\
-\cdots \\
-\cdots \\
-\cdots \\
\cdots \\
-\end{array}$ & $\begin{array}{l}92.9 \\
89.4 \\
86.9 \\
85.2 \\
84.7 \\
85.4 \\
87.0\end{array}$ & $\begin{array}{l}.0509 \\
\text { a. } 0467 \\
\text { a. } 0435 \\
\text { a. } 0409 \\
\text { a. } 0392 \\
\text { a. } 0385 \\
\text { a. } 0384\end{array}$ & 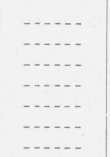 & 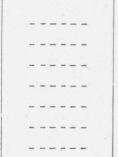 & $\begin{array}{l}.0509 \\
.0457 \\
.0435 \\
.0409 \\
.0392 \\
.0385 \\
.0384\end{array}$ & $\begin{array}{c}68.3 \\
-\cdots \\
\cdots \\
\cdots \\
-\cdots \\
-\end{array}$ & $\begin{array}{l}68.3 \\
64.4 \\
61.5 \\
59.2 \\
58.1 \\
58.2 \\
59.1\end{array}$ \\
\hline
\end{tabular}

a From 730 to $750 \mathrm{~m} \mu$ these values are derived from the published data of [?]

From 760 to $780 \mathrm{~m} \mu$ the values are derived from the data of tabla 1 .

and $\mathrm{C}$ filters prepared according to the specifications. These consisted of two-compartment glass cells (1ndex 1.52 ) filled with the appropriate solutions prepared in the respective years. The filters were kept at $25^{\circ} \mathrm{C}$ during the measurements. The average values so obtained are given in table 3 . These are as directly observed, without any adjustment. (No values are given at 404.7 and $435.8 \mathrm{~m} \mu$, because data at these wavelengths were not published in [2 and 7] for the filters themselves.)

\section{c. New Values}

In table 3 , in addition to the computed and observed values of spectral transmittance, are given the new transmittance values for filters $\mathrm{B}$ and $\mathrm{C}$, together with the values previously derived by the methods and data of [2]. With respect to the new values it may be noted that:

1. The former values are retained without change from 380 to $400 \mathrm{~m} \mu$. This is highly desirable, as already implied, because these values from 380 to 400 $\mathrm{m} \mu$ were incorporated in the energy distributions of sources B and C in 1931, and have been used in thousands of colorimetric computations since that date. ${ }^{10}$ If the 1950-51 values differed certainly and importantly from the former values from 380 to 400 $\mathrm{m} \mu$, serious consideration would have to be given to changing the standard values. However, inspection of the data of table 3 at these wavelengths shows that in only one case out of 12 (observed value at $380 \mathrm{~m} \mu$ for the $\mathrm{C}$ filter) does a computed or observed 1950-51 value differ from the former value by as much as 1 percent of the value.

\footnotetext{
10 Although the CIE adopted values of energy distribution also at $370 \mathrm{~m} \mu$, the standard observer was defined by data ending at $380 \mathrm{~m} \mu$. The energy values at $370 \mathrm{~m} \mu$, so far as known, have never been used in colorimetric computations. The authors, therefore, felt free to revise both the values of transmittance and the resulting energy at $370 \mathrm{~m} \mu$.
}

2. At 3oi) $\mathrm{m} \mu$ the slight absorption found in the 1950-51 borosilicate crown glass plates is reflected in the relatively low values for both the computed and observed data for both the B and the C filters. However, even if it were not desirable to retain the values at $380 \mathrm{~m} \mu$, for the reason just stated, one would hesitate to make any change on the basis of the present data alone, without a thorough study of borosilicate crown glass plates.

3. From 320 to $370 \mathrm{~m} \mu$ the new values are taken as the average of the observed and computed values. While one might believe that the observed values should be given more weight than the computed values, the experimental conditions render the measurements somewhat more difficult and uncertain in the former case. Furthermore, at the very low values of transmittance the computed values are considered more reliable than the directly observed values.

4. The values of transmittance at $720 \mathrm{~m} \mu$ are as given in figures 2 and 3 . The values of transmittance from 730 to $780 \mathrm{~m} \mu$ are derived from the data of table 1 or the published data of [2] by the same computational procedures used to derive the corresponding values of figures 2 and 3 at the other wavelengths.

\subsection{Light Sources B and C}

The values of relative spectral energy distribution for sources $\mathrm{B}$ and $\mathrm{C}$ are derived by multiplying, wavelength by wavelength, the relative-energy values of source A by the respective spectral transmittances of filters $\mathrm{B}$ and $\mathrm{C}$, and reducing in each case by a factor to the same scale as used in [2].

In table 3 are given the values of relative energy for sources B and C, first the former values, which are consistent with the data of [2], and then as revised on 
TABLE 4. Relative spectral-energy distributions $E$ of CIE light sources $A, B$, and $C$, and spectral transmittances $T$ of $C I E$ filters $B$ and $C$

\begin{tabular}{|c|c|c|c|c|c|}
\hline $\begin{array}{l}\text { Wave- } \\
\text { length }\end{array}$ & $E_{A}$ & $E_{B}$ & $E_{C}$ & $T_{B}$ & $T_{C}$ \\
\hline $\begin{array}{r}m \mu \\
320 \\
30 \\
40\end{array}$ & $\begin{array}{l}1.92^{\mathrm{a}} \\
2.66 \\
3.58\end{array}$ & $\begin{array}{l}0.0_{2} \\
.5 \\
2.4\end{array}$ & $\begin{array}{l}0.0_{1} \\
.4 \\
2.7\end{array}$ & $\begin{array}{r}0.003 \\
.048 \\
.175\end{array}$ & $\begin{array}{r}0.001 \\
.025 \\
.120\end{array}$ \\
\hline $\begin{array}{r}350 \\
60 \\
70 \\
80 \\
90\end{array}$ & $\begin{array}{r}4.74 \\
6.14 \\
7.82 \\
0.79 \\
12.09\end{array}$ & $\begin{array}{r}5.6 \\
9.6 \\
15.2 \\
22.4 \\
31.3\end{array}$ & $\begin{array}{r}7.0 \\
12.9 \\
21.4 \\
33.0 \\
47.4\end{array}$ & $\begin{array}{l}.301 \\
.402 \\
.498 \\
.588 \\
.666\end{array}$ & $\begin{array}{l}.231 \\
.330 \\
.429 \\
.529 \\
.615\end{array}$ \\
\hline $\begin{array}{r}400 \\
10 \\
20 \\
30 \\
40\end{array}$ & $\begin{array}{l}14.71 \\
17.68 \\
21.00 \\
24.67 \\
28.70\end{array}$ & $\begin{array}{l}41.3 \\
52.1 \\
63.2 \\
73.1 \\
80.8\end{array}$ & $\begin{array}{r}63.3 \\
80.6 \\
98.1 \\
112.4 \\
121.5\end{array}$ & $\begin{array}{l}.721 \\
.757 \\
.774 \\
.761 \\
.723\end{array}$ & $\begin{array}{l}.675 \\
.714 \\
.733 \\
.714 \\
.663\end{array}$ \\
\hline $\begin{array}{r}450 \\
60 \\
70 \\
80 \\
90\end{array}$ & $\begin{array}{l}33.09 \\
37.82 \\
42.87 \\
48.25 \\
53.91\end{array}$ & $\begin{array}{l}85.4 \\
88.3 \\
92.0 \\
95.2 \\
96.5\end{array}$ & $\begin{array}{l}124.0 \\
123.1 \\
123.8 \\
123.9 \\
120.7\end{array}$ & $\begin{array}{l}.663 \\
.601 \\
.551 \\
.507 \\
.460\end{array}$ & $\begin{array}{l}.587 \\
.511 \\
.453 \\
.402 \\
.351\end{array}$ \\
\hline $\begin{array}{r}500 \\
10 \\
20 \\
30 \\
40\end{array}$ & $\begin{array}{l}59.86 \\
66.06 \\
72.50 \\
79.13 \\
85.95\end{array}$ & $\begin{array}{l}94.2 \\
90.7 \\
89.5 \\
92.2 \\
96.9\end{array}$ & $\begin{array}{r}112.1 \\
102.3 \\
96.9 \\
98.0 \\
102.1\end{array}$ & $\begin{array}{l}.404 \\
.353 \\
.317 \\
.300 \\
.290\end{array}$ & $\begin{array}{l}.293 \\
.243 \\
.210 \\
.194 \\
.186\end{array}$ \\
\hline $\begin{array}{r}550 \\
60 \\
70 \\
80 \\
90\end{array}$ & $\begin{array}{r}92.91 \\
100.00 \\
107.18 \\
114.44 \\
121.73\end{array}$ & $\begin{array}{r}101.0 \\
102.8 \\
102.6 \\
101.0 \\
99.2\end{array}$ & $\begin{array}{r}105.2 \\
105.3 \\
102.3 \\
97.8 \\
93.2\end{array}$ & $\begin{array}{l}.279 \\
.264 \\
.246 \\
.227 \\
.209\end{array}$ & $\begin{array}{l}.178 \\
.165 \\
.1497 \\
1338 \\
1199\end{array}$ \\
\hline $\begin{array}{r}600 \\
10 \\
20 \\
30 \\
40\end{array}$ & $\begin{array}{l}129.04 \\
136.34 \\
143.62 \\
150.83 \\
157.98\end{array}$ & $\begin{array}{r}98.0 \\
98.5 \\
99.7 \\
101.0 \\
102.2\end{array}$ & $\begin{array}{l}89.7 \\
88.4 \\
88.1 \\
88.0 \\
87.8\end{array}$ & $\begin{array}{l}.195 \\
.186 \\
.178 \\
172 \\
.166\end{array}$ & $\begin{array}{l}.1090 \\
.1016 \\
.0961 \\
.0914 \\
.0871\end{array}$ \\
\hline $\begin{array}{r}650 \\
60 \\
70 \\
80 \\
90\end{array}$ & $\begin{array}{l}165.03 \\
171.96 \\
178.77 \\
185.43 \\
191.93\end{array}$ & $\begin{array}{l}103.9 \\
105.0 \\
104.9 \\
103.9 \\
101.6\end{array}$ & $\begin{array}{l}88.2 \\
87.9 \\
86.3 \\
84.0 \\
80.2\end{array}$ & $\begin{array}{l}.162 \\
.157 \\
.151 \\
.1440 \\
.1360\end{array}$ & $\begin{array}{l}.0838 \\
.0801 \\
.0756 \\
.0710 \\
.0654\end{array}$ \\
\hline $\begin{array}{r}700 \\
10 \\
20 \\
30 \\
40\end{array}$ & $\begin{array}{l}198.26 \\
204.41 \\
210.36 \\
216.12 \\
221.66\end{array}$ & $\begin{array}{l}99.1 \\
96.2 \\
92.9 \\
89.4 \\
86.9\end{array}$ & $\begin{array}{l}76.3 \\
72.4 \\
68.3 \\
64.4 \\
61.5\end{array}$ & $\begin{array}{l}.1284 \\
.1210 \\
.1134 \\
.1063 \\
.1007\end{array}$ & $\begin{array}{l}.0604 \\
.0555 \\
.0509 \\
.0467 \\
.0435\end{array}$ \\
\hline $\begin{array}{r}750 \\
60 \\
70 \\
80\end{array}$ & $\begin{array}{l}227.00 \\
232.11 \\
237.01 \\
241.67\end{array}$ & $\begin{array}{l}85.2 \\
84.7 \\
85.4 \\
87.0\end{array}$ & $\begin{array}{l}59.2 \\
58.1 \\
58.2 \\
59.1\end{array}$ & $\begin{array}{l}.0964 \\
.0938 \\
.0926 \\
.0925\end{array}$ & $\begin{array}{l}.0409 \\
.0392 \\
.0385 \\
.0384\end{array}$ \\
\hline
\end{tabular}

a $E_{A}=0.93$ at $300 \mathrm{~m} \mu$ and 1.36 at $310 \mathrm{~m} \mu$.

the basis of the new spectral transmittances. The following points may be noted: (1) The values from 380 to $400 \mathrm{~m} \mu$ are kept unchanged. This follows from the fact that the new spectral transmittances are kept unchanged at these wavelengths, for the reason already stated. (2) From 350 to $370 \mathrm{~m} \mu$ the new values do not differ importantly from the former values. For source B they are not considered certainly different except at $350 \mathrm{~m} \mu$. For source C the new values are considered certainly different from the old values at both 350 and $360 \mathrm{~m} \mu$. (3) Effective termination of the energy distribution at $320 \mathrm{~m} \mu$ results primarily from the absorption of the copper-pyridine component, with the increasing absorption of the glasses and the decreasing energy of source A contributing secondarily.

\section{Final Data}

As a matter of convenient reference there are given in table 4 over the spectral range from 320 to $780 \mathrm{~m} \mu$ the relative spectral-energy distributions of CIE sources $\mathrm{A}, \mathrm{B}$, and $\mathrm{C}$ and the spectral transmittances of filters $B$ and $C$.

For source A, the values from 380 to $780 \mathrm{~m} \mu$ are identical with those published by Smith and Guild [3] and by Judd [4]. From 320 to $370 \mathrm{~m} \mu$ the values have been derived by the authors from previous publications $[10,11]$, with allowance for differences in $c_{2}$ of Planck's equation.

For sources B and C the values from 380 to $720 \mathrm{~m} \mu$ are identical with the published CTE values ${ }^{11}[1]$, and with values published by Smith and Guild "[3] and by Judd [4]. From 320 to $370 \mathrm{~m} \mu$ the values are taken from table 3 of the present paper. From 730 to $780 \mathrm{~m} \mu$, the values are as published by Smith and Guild and by Judd.

For filters B and C the values from 380 to $720 \mathrm{~m} \mu$ are unchanged from previous data. From 320 to 370 and from 730 to $780 \mathrm{~m} \mu$, the values are taken from table 3 of the present paper.

\section{References}

[1] CIE Compt. rend. p. 19-29 (1931).

[2] Raymond Davis and K. S. Gibson, Filters for the reproduction of sunlight and daylight and the determination of color temperature, NBS Misc. Pub. No. 114 (1931)

[3] T. Smith and J. Guild, The C. I. E. colorimetric standards and their use, Trans. Opt. Soc. (London) 33, 73 (1931$32)$.

[4] Deane B. Judd, The 1931 I. C. I. standard observer and coordinate system fcr colorimetry, J. Opt. Soc. Am. 23, 359 (1933).

[5] CIE, Compt rend 1, Tech. Rept. 7, p. 11 (1951).

[6] Deane B. Judd, Color in business, science, and industry p. 96 (John Wiley \& Sons, Inc., New York, N. Y., 1952).

[7] Raymond Davis and K. S. Gibson, The relative spectral energy distribution and correlated color temperature of the N. P. L. white-light standard, BS J. Research 7,791 (1931) RP374.

[8] CIE, Compt. rand.p. 16, 238 (1948).

[9] CIE, Compt. rand 3, 116 (1951).

[10] R. Stair and W. O. Smith, A tungsten-in-quartz lamp and its applications in photoelectric radiometry, J. Resəarch NBS 30, 449 (1943) RP1543.

[11] J. F. Skogland, Tables of spectral energy distribution and luminosity for use in computing light transmissions and relative brightnesses from spectrophotometric data, NBS Misc. Pub. 86 (1929).

11 Except for the erroneous published value at $380 \mathrm{~m} \mu$ for source C.

Washington, August 28, 1952. 